\title{
Corrigendum: Reconstructed Russian Fisheries Catches in the Barents Sea: 1950-2014
}

\author{
Sarah Popov ${ }^{1 *}$ and Dirk Zeller ${ }^{2}$ \\ ${ }^{1}$ Sea Around Us, Global Fisheries Cluster, University of British Columbia, Vancouver, BC, Canada, ${ }^{2}$ Sea Around Us - Indian \\ Ocean, School of Biological Sciences, University of Western Australia, Crawley, WA, Australia
}

Keywords: trawling, discards, cooperation, unreported catches, industrial fisheries, artisanal fisheries, subsistence fisheries

\section{OPEN ACCESS}

Approved by:

Frontiers in Marine Science Editorial Office,

Frontiers Media SA, Switzerland

${ }^{*}$ Correspondence:

Sarah Popov

popovs@uwindsor.ca

Specialty section:

This article was submitted to Marine Fisheries, Aquaculture and

Living Resources, a section of the journal Frontiers in Marine Science

Received: 11 January 2019

Accepted: 21 January 2019

Published: 07 February 2019

Citation:

Popov S and Zeller D (2019) Corrigendum: Reconstructed Russian Fisheries Catches in the Barents Sea: 1950-2014. Front. Mar. Sci. 6:33. doi: 10.3389/fmars.2019.00033

\section{A Corrigendum on}

Reconstructed Russian Fisheries Catches in the Barents Sea: 1950-2014

by Popov, S., and Zeller, D. (2018). Front. Mar. Sci. 5:266. doi: 10.3389/fmars.2018.00266

In the original article, there was a mistake in Table 3 as published. The "Northern shrimp" fishery was incorrectly cited as being divided into 93\% "Bottom trawl" and 7\% "Longline," and the incorrect source was cited. The corrected Table 3 appears below.

The authors apologize for this error and state that this does not change the scientific conclusions of the article in any way. The original article has been updated.

\section{REFERENCES}

ICES (2015a). Report of the Arctic Fisheries Working Group (AFWG). Hamburg: ICES

Wienerroither, R., Johannesen, E., Dolgov, A., Byrkjedal, I., Bjelland, O., Dreventnyak, K., et al. (2011). Atlas of the Barents Sea Fishes. IMR/PINRO Joint Report Series (IMR/PINRO).

Conflict of Interest Statement: The authors declare that the research was conducted in the absence of any commercial or financial relationships that could be construed as a potential conflict of interest.

Copyright (C) 2019 Popov and Zeller. This is an open-access article distributed under the terms of the Creative Commons Attribution License (CC BY). The use, distribution or reproduction in other forums is permitted, provided the original author(s) and the copyright owner(s) are credited and that the original publication in this journal is cited, in accordance with accepted academic practice. No use, distribution or reproduction is permitted which does not comply with these terms. 
TABLE 3 | Percentage composition of catch by fishing gear types within Russian Barents Sea fisheries.

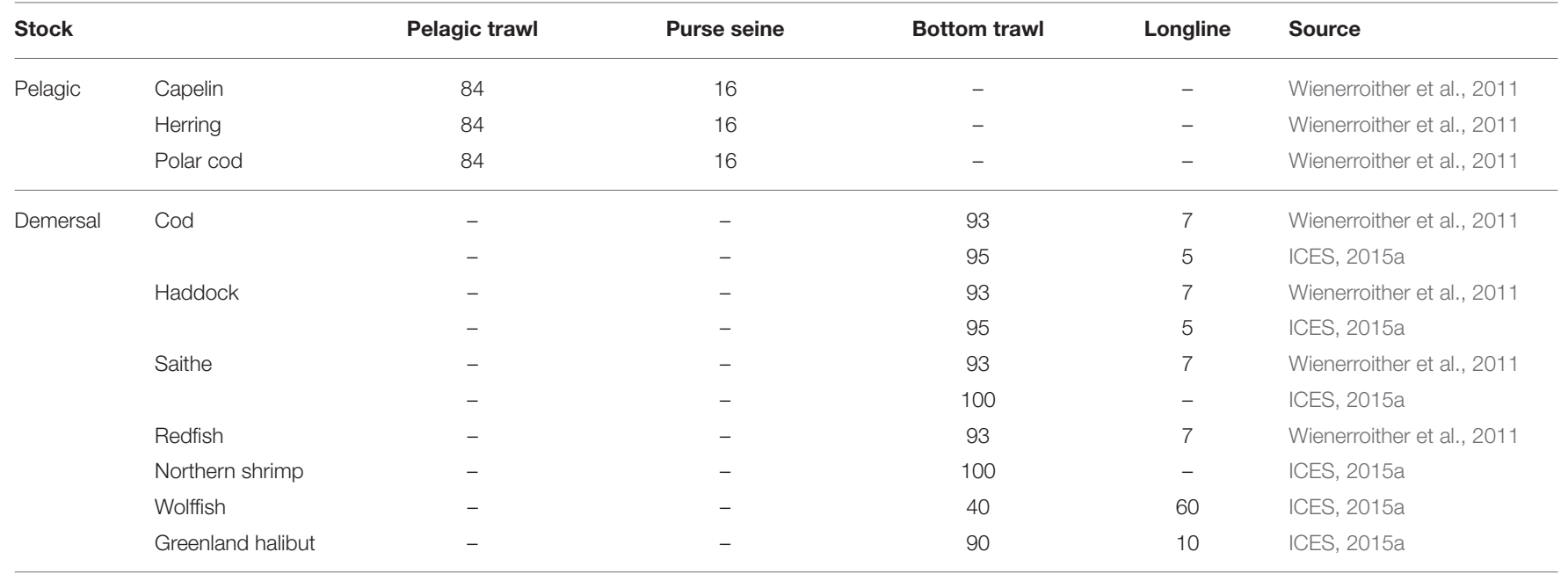

